\title{
THE INFLUENCE OF BLUE CODE OF SILENCE ON WHISTLEBLOWING (INTERNAL REPORTING) IN PERSONNEL OF SEMARANG POLICE RESORT CRIMINAL INVESTIGATION
}

\author{
${ }^{1}$ Robinson Lumban Raja, robinsonlraja64@gmail.com \\ ${ }^{2}$ Resandro Handriajati \\ ${ }^{1,2}$ Indonesian Police Science College
}

\begin{abstract}
Citation :
Lumban Raja Robinson, Resandro Handriajati, The Influence Of Blue Code Of Silence On Whistleblowing(Internal Reporting) In Personnel Of Semarang Police Resort Criminal Investigation, Management Technology and Security International Journal, page 51-75
\end{abstract}

Received on 6 June 2020, Accepted on 09 July 2020, Published on 1 August 2020

\begin{abstract}
The performance of Indonesian National Police according to public view is still far from good mark because there is still the Blue Code of Silence that protected the corrupt police from Whistleblowing. Blue Code of Silence is a culture of the police in which members of the police are prohibited from reporting violations or crimes committed by other police members. The purpose of this study was to determine the effect of the Blue Code of Silence on Whistleblowing on the members The Criminal Investigation Department of Semarang City Police Regency directly, partially and simultaneously. This research was conducted with quantitative approach and carried out at Semarang City Police Regency. The population in this study were 150 members of Semarang Criminal Police Department with the sample used based on the Slovin formula totaling 60 respondents. The analysis technique used in this research is descriptive data analysis and inferential data analysis. The main research results in this study were that a significant effect was found regarding the Blue Code of Silence on Whistleblowing in The Criminal Investigation Department of Semarang City Police Regency. The results of this study indicate that most members of the Semarang Police Criminal Investigation Department are still reluctant to report other police officers who committed violations or crimes. From these results it can be concluded that the Blue Code of Silence culture still became culture in members of The Criminal Investigation Department of Semarang City Police Regency; Partially, members of the The Criminal Investigation Department of Semarang City Police Regency are afraid of retaliation when conducting Whistleblowing; and simultaneously, loyalty factors, the seriousness of violations, fear of retaliation and leadership influence have an influence on the occurrence of Blue Code of Silence and the lack of Whistleblowing on members of the Semarang Criminal Investigation Department.
\end{abstract}

Keywords: Semarang City Police Regency, Blue Code of Silence, Whistleblowing, Corruption in the Police 


\section{INTRODUCTION}

\subsection{Background}

The great challenge of the Indonesian people after independence is the fight against corruption. Weapons to fight corruption cases have been well prepared starting from: the formation of Law Number 24 of 1960 concerning the Investigation, Prosecution and Examination of Corruption; Law Number 3 of 1971 concerning Eradication of Corruption; Law Number 31 of 1999 jo Law Number 20 of 2001 concerning Eradication of Corruption Crimes; Law Number 30 of 2002 concerning the Corruption Eradication Commission; Law Number 46 of 2009 concerning Corruption Criminal Court and the latest is a plan to revise Law Number 30 of 2002 concerning Corruption Eradication Commission which is planned to be ratified in the 9th plenary session of 2019-2020.

Corruption is a form of cheating and is the main enemy of every country in the world. According to Graycar and Prenzel (2013: 19), Corruption is a result of the interaction between primary human needs with an economic and social condition in order to meet those needs. A similar opinion was expressed by Jain (2001 in Jain, 2017: 1) which states that corruption is an abuse of authority committed by a state employee for personal gain. Corruption in Indonesia places Indonesia at 38 and ranks 89th out of 180 countries in the 2018 Global Corruption Perception Index (Transparency International, 2019). One of the other steps in addition to preparing the aforementioned set of regulations, the Government of Indonesia has also adopted a pattern of structure and mechanism in the management of governance that has long-term and sustainable economic value through the application of good governance principles as an effort to prevent corruption in Indonesia. The application of the principle of good governance can be successful if it is supported by the ethics of good corporate governance, which is an effort to create good governance in the form of good governance that can be implemented with a whistle blowing system.

The Whiste blowing system applied in an organization is a guideline for reporting violations that contains ethics that refer to standards of behavior in the community that are considered bad deeds and good deeds, which deeds should not be done and which deeds should be done, so This ethic forms a standard of behavior, it recommends how a person in the community must behave in various situations that must be faced. In addition, work ethics must also be applied both when working when carrying the name of the organization, as well as when dealing with and interacting with other members, while in this work ethic is prepared based on general ethical principles in the implementation of good governance (Saha, 2014 : 47).

One of the organizations in the Indonesian Government environment that is still widely reported by the public regarding performance issues is the National Police organization. Based on the results of a survey from the Ombudsman in 2018, it was found that the National Police organization still ranked second with a total of 212 reports. (Ombudsman of the Republic of Indonesia, 2019: 5)

Based on the data above, it is known that public reporting indicates disappointment with the performance of the National Police organization. This can be caused by several things, both the delay in Police Republic of Indonesian 's services and the suspicion of fraud in which the perpetrators are individual Police Republic of Indonesian members when providing services to the public. To overcome the problem of fraud in Police Republic of Indonesian services to the public, especially in the context of overcoming behavioral problems that are not in 
accordance with the ethics of the National Police, the National Police has now implemented a whistle blowing system intended as a means of informing the existence of violations of the ethics of Police Republic of Indonesian members without any concern experienced by the reporter because this system guarantees the confidentiality of the reporter's identity.

The importance of implementing a whistle blowing system is also used to prevent internal corruption, as was the case with internal police corruption in 2011, with the proof of the SIM simulator corruption case committed by the National Police Inspector General Inspector General. Djoko Susilo and Brigjen Pol. Didik Purnomo who was proven to have received bribes in projects worth more than Rp. 189 Billion, as well as cases of receiving bribes in handling the fictitious Letter of Credit (LC) case of BNI conducted by Brigjen Pol. Ismoko (Fefy Haryanto, 2017). The existence of these two cases was very public attention,

so as to anticipate violations of the code of conduct in the internal Police of the Republic of Indonesia the whistle blowing system is currently being implemented, where the program is aimed at preventing, eliminating and reducing violations committed by members of the National Police.

The whistle blowing system is implemented to prevent violations of the code of ethics internally within the Indonesian National Police. The mechanism can only be carried out by fellow members of the Indonesian National Police by presenting a chronology of events and attaching evidence of violations of the code, be it data, documents, pictures or records. However, this condition is hindered by the unwritten norms that have been entrenched in the organization, which seems to limit the behavior of every Police Republic of Indonesian member to carry out reporting actions against his own colleague (Blue Blue Code of Silence), so that the existence of these norms tends to create passive awareness the member himself is to report on acts of fraud or violations of the code of ethics committed by the member, so this hinders law enforcement efforts against his colleague.

Ivkovic and Shelley (2014: 446) explain that the police tend to be minimal in reporting fraud or violations committed by their own colleagues into the whistle blowing system. This condition is caused by the existence of unwritten norms that make it tend to remain silent and not report the case (Blue Blue Code of Silence), so this makes weak law enforcement against fellow members of the police force.

Inequality in research results or the rejection of research findings conducted by Ivkovic and Shelley (2014: 446) are called for by Marshall (2019: 116), which states that in his research conducted through interviews with a number of members of the police officers and former police officers in Canada evade unwritten norms that limit the behavior of every Police Republic of Indonesian member to carry out reporting actions against his own colleague or give a statement regarding the rejection of the reality of the Blue Blue Code of Silence despite the fact that the tradition of shut up in the Ontario police organization is very strong. From some of these studies, it can be concluded that the Blue Code of Silence culture is found in several police institutions in various countries. This is of course contrary to the principle of police which in law enforcement ideally there is no term "selective logging" because it is contrary to the principle of equality before the law.

Based on the existence of two different research findings, the researcher is interested in examining the application of the whistle blowing system in the National Police organization and the existence of the Blue Code of Silence norm. To find out the interrelationship between the two variables, the right research is to describe the understanding of each Police Republic of Indonesian member of the reality of the 
two variables using the quantitative method. With this research model, Police Republic of Indonesian members' perspectives on the whistle blowing system will be opened, the Blue Code of Silence norms and the relationship between the two variables so that the results of this study are not only intended to explain the gaps in the findings of previous research as applied in the National Police organization. This research is also useful to increase public understanding related to Police Republic of Indonesian organizations and facilitate increased Police Republic of Indonesian accountability and publicly demonstrate the culture of good governance in Police Republic of Indonesian organizations.

1.2. Formulation of the problem

Based on the explanation from the background, the formulation of the problem of this research are:

Is there a direct influence of the Blue Code of Silence on whistleblowing at the Semarang Police Resort Criminal Investigation Unit?

Does loyalty, seriousness of violations, fear of retaliation and influence of the leadership partially influence whistleblowing at the Semarang Police Resort Criminal Investigation Unit?

Does loyalty, seriousness of violations, fear of retaliation and influence of leaders simultaneously influence whistleblowing at at the Semarang Police Resort Criminal Investigation Unit?

\subsection{Purposes}

Analyzing the effect of the Blue Code of Silence on whistleblowing at the Semarang Police Resort Criminal Investigation Unit? Analyzing the influence of loyalty, the seriousness of violations, fear of retaliation and partial influence of the leadership of the whistleblowing at the Semarang Police Resort Criminal Investigation Unit? Analyzing the influence of loyalty, the seriousness of violations, fear of retaliation and the influence of the leadership simultaneously on whistleblowing at the Semarang Police Resort Criminal Investigation Unit?

\section{LITERATURE REVIEW}

\subsection{Police Leadership Style}

The police force is a civilian organization that operates according to the command baseline where the command area is divided from the smallest level, namely the police station which is then commanded by the police, police and police headquarters which are regulated by Presidential Decree No.52 of 2010 (President of the Republic of Indonesia, 2010: 3). The leadership style based on command is a militaristic leadership style where subordinates carry out superior orders. Yuniarti (2011: 114) states that the police leadership style has not experienced much change since the New Order era in which the police are still considered a militaristic governmental organization.

Militaristic Leadership Style according to the British Defense Doctrin (2001 in Soemanagara, 2011: 23) is a leadership style that has the aim to provide and incorporate an attitude and characteristics so that coworkers do the work that has been assigned. Keller (2014: 39) mentions that militaristic leadership is leadership which emphasizes that orders must be carried out. This is in line with the Police Republic of Indonesian 's system of work wherein giving tasks to members by making a warrant scheme in which members must work in accordance with what is written in the warrant.

This militaristic leadership style is a leadership style which is influenced by components, namely loyalty, obligation, mutual respect, work without thinking of 
oneself, honor, integrity and personal enthusiasm (Soemanagara, 2003: 21). The leadership style here tends to carry out the leadership's orders and is reluctant to refuse them even though in fact the police itself have regulated the discretion of the police but the policy maker is still the leader.

\subsection{Police Management}

Robbins and Coulter (2012: 36) defines management as a process of how to coordinate and integrate various work activities so that it can be completed to the maximum. Syafaruddin (2005: 14) defines management as the process of cooperation that exists between individuals and groups to obtain goals by doing work effectively and efficiently. Griffin (2008: 7) explains that management is a series of activities that begin with planning to control which serves to provide a handle on existing resources to achieve goals. From the three opinions above we can know that management itself is a process which requires cooperation from each party or group in order to obtain maximum results. Terry (1958 in Sukarna, 2011: 10) divides four stages in the management process, namely Planning, Organizing, Actuating and Controlling.

Management in the police organization in Indonesia is a management that has objectives in accordance with Article 13 of Law No. 2 of 2002 concerning the State of the Police where the police aims to maintain public security and order, enforce the law and provide protection, protection and community services . In the management of the police organization, it is regulated in Presidential Regulation No.52 of 2010 concerning the Organizational Structure and Work
Procedure of the Republic of Indonesia National Police where the police work system is divided into four levels, namely the National Police Headquarters, Regional Police, Polres and Polsek which are led by a Head and Deputy Head and have a straight line of command at the National Police Headquarters with the highest leadership, namely the Indonesian National Police Chief.

The management system in the Police itself includes planning, organizing, implementing and controlling. Supervision of members is included as one element of control where control is intended so that members do not violate discipline or violate positive law. This control can be done either in a warrant which is usually always included personnel from the professional division and security for the implementation of internal security and by the Head appointed as the leader written on the warrant which then the results of the report will be identified and studied by the main leadership. The Blue Code of Silence is a culture which occurs when the leader or members who conduct surveillance allow violations or crimes to occur.

\subsection{Blue Code of Silence}

The Blue Code of Silence is a subculture of the police which is an unwritten norm or regulation that has become a culture that exists in the police institution. Skolnick (2002: 8) defines the Blue Code of Silence as an act where police officers refuse to report irregularities committed by their coworkers or to falsely claim no knowledge of violations. In line with Skolnick, Hope Sr. (2016: 14) explains that the Blue Code of Silence is a deviant behavior from members of the police force 
in which a member of the police does not want to report violations committed by other police members.

One of the preliminary studies of the Blue Code of Silence was carried out in the 1970s by Westley (in Ivkovic et al. 2018: 1) which stated that more than $70 \%$ of police officers did not want to report other members who were extorting drunk people. In line with the results of previous studies, the results of research studied by Weisburd (2000: 3) show that although members of the police are not agreeing with the deviant behavior of the other members, the member remains reluctant to report irregularities committed by his friend. Skolnick (2002: 8) states that the reason for the existence of the Blue Code of Silence is loyalty to fellow members and fear of retaliation from other police members.

The existence of the Blue Code of Silence culture in this police force will result in omission and may be able to cover up corruption committed by members of the police which can damage the foundation of the law enforcement system (Ivkovic and Shelley, 2008: 447). Of course, the existence of a culture like this will make a negative tolerance from a good police officer to a bad police member so that the police image as a law enforcement institution will get worse. The Blue Code of Silence itself violates the principle of equality before the law. This is because this culture prevents bad police officers from being prosecuted in court.

To know the cultures of the Blue Code of Silence in an organization this can be seen from the following dimensions:

1). Loyalty
Loyalty in a semi-military organization such as the police force has very strong roots in the organization (Wieslander, 2019: 310). This is because the spirit of spirit de corps owned by the police which was formed since education. The spirit of mutual protection, mutual assistance is the most basic and becomes a guide for every member of the police who has participated in the basic activities of forming police officers.

In practice, a sense of loyalty between members does not only apply to good things but also to bad things. Ivkovich (2005: 80) explains that this blind loyalty causes members of the police to join together in seeing and fighting a threat or it can be called "we fight them". In Hong Kong itself there are terms such as "don't stand in front of the bus" which means that members are prohibited from reporting the matter or indirectly asking members who report it to be silent.

Blind loyalty to acts that violate the law is considered a very bad deed (Ivkovich, 2015: 307). This is because this blind loyalty can confuse and poison the way of thinking of members of the police, especially new members who join the police institution. As a result, honest police officers will be affected and forced to follow their seniors and colleagues on behalf of loyalty and do not want other members or leaders as well as the police's good reputation to be polluted the actions of police officers.

\section{2). Seriousness of the Violation}

The level of seriousness of violations committed by members of the police is considered as one of the reasons that affects the desire of members to report 
other members. The same result was also found by researchers in the United States conducted by Klockars et al (2000: 9) showing that police officers were reluctant to report irregularities that police officers considered to be not serious, not too severe or had little sentence. The same results were also found by researchers at Ivkovich and Shelley (2018: 448), grouping this police behavior into 10 scenarios where dividing some police irregularities by the degree of seriousness of violations committed by the police. This began with the gift given by a merchant colleague to violence in order to obtain information in the investigation. In this case there is a striking difference where in deviations that are considered trivial or not too severe by members of the police it is almost impossible for members of the police to report

Tabel 1 Percentage for not reporting on violation

\begin{tabular}{|l|l|r|}
\hline No & \multicolumn{1}{|c|}{ Scenario } & Percentage for not reporting \\
\hline 1 & Business holiday for officers getting off picket & $54,2 \%$ \\
\hline 2 & Free food and discounted prices & $41 \%$ \\
\hline 3 & Bribery from violations of motor vehicle speed & $20,1 \%$ \\
\hline 4 & Holiday gift from merchants & $65,9 \%$ \\
\hline 5 & Theft at the crime scene & $11,1 \%$ \\
\hline 6 & Bribery from collusion with workshop operators & $25,7 \%$ \\
\hline 7 & Bribery towards superiors to get a day off & $33,1 \%$ \\
\hline 8 & $\begin{array}{l}\text { Manipulation in the case of motorists driving } \\
\text { drunk and accidents }\end{array}$ & $40,5 \%$ \\
\hline 9 & Excessive use of violence & $46,0 \%$ \\
\hline 10 & Theft from a wallet found & $15,9 \%$ \\
\hline
\end{tabular}

Source : Ivkovich dan Shelley (2018:455)

\section{3). Fear of retaliation}

One of the reasons why members of the police do not want to report other members of the police who have committed deviant acts is because the member is afraid of retaliation either by the perpetrators of the deviation or a fellow police member. In Wieslander's research (2019: 315), one of the informants gave information that members who reported other members would get replies such as demotion and even bullying which resulted in the member surrendering and leaving the police institution. This shows that a report against another colleague is an act that is hated by other police members which can result in verbal and physical attacks on the 
perpetrators who do the reporting. As a result, the fear of retaliation caused members of the police to choose silence to see something that deviated before him.

\section{4). Influence of leadership}

In a police system, the role of a superior is very important in suppressing the norms of the Blue Code of Silence in a working group. Ivkovic (2008: 447) argues that superiors are very instrumental in preventing corrupt behavior from the police including the implementation of the norm of the Blue Code of Silence itself. This opinion is reinforced by Rothwell and Baldwin (2007: 346) who argue that a supervisor is responsible for all the behaviors and deeds of subordinates in carrying out their duties. A supervisor has the authority to see, manage and assess the behavior and activities of members with the responsibility to guarantee the course of an organization.

The National Police System of the Republic of Indonesia adheres to a hierarchical tiered system where each member of the police force is divided into a system of units, sections, functions and work units. In a tiered system the oversight responsibilities are distinguished from rank and position structures. This is supported by the culture of the police in Indonesia itself, although it has shifted to civilian police organizations, but it has not yet lost the commando or militaristic leadership style. For example, such as in a unit where supervision is carried out by a Unit Head where the Unit Head is then supervised by the Chief of the Bin Ops who then steps from the Head of Unit to the Head of the Resort Police.

Rothwell and Baldwin (2007: 346) argue that a boss has the responsibility for the task and authority to report any violations committed by its members. This opinion is reinforced by the results of research from Wieslander (2019: 318) which mentions that indirectly, superiors can teach Blue Code culture

of Silence against new members of the police force who become his subordinates. Bosses who do not want to listen to suggestions and input from members regarding the mistakes that have been made will make police members to choose silence.

Ideally, leaders should not be able to apply the Blue Code of Silence to other members so that the implementation of organizational goals can run well. A boss should be brave to admit mistakes and dare to report mistakes and report members who make mistakes so that they can provide an example for their members to do the same.

Based on the various explanations above, a conclusion regarding the Blue Code of Silence which is a tradition that is within the scope of members in each Police Republic of Indonesian institution as will be the object of this research can be seen based on the dimensions of loyalty, seriousness of violations, fear of retaliation and leadership influence .

The results of research conducted by Sarah Marshall (2019: 6) in which she explained the background behind this research is to express criticism of police officers who tend to prioritize the Blue Code of Silence related to ethical code violations, disciplinary violations, abuse of office authority to corruption in internal police organization. Sarah Marshall's research (2019: 11) aims to gain a better understanding of police institutions, the 
role of the police, and the reasons behind their decision making and to educate the public about policing in the liberal democratic order.

This is intended so that the state and the public can criticize the role of the police and can hold accountability regarding police actions taken.

Sarah Marshall (2019: 11) was carried out using qualitative methods and using a meta-analytical approach to symbolic interactionism and critical discourse analysis to explain the perspectives, experiences and decisions of the police officers interviewed related to the perspective of the Blue Code of Silence. The results of Sarah Marshall's research (2019) explain that: the state monopolizes the legitimate use of force; the growing bureaucracy tends to be full of secrecy, the protection of their members and the 'outsider' exclusion; and free authority or power tends to be corrupted.

The relevance of Sarah Marshall's research literature (2019: 6) with this research is that they both discuss the Blue Code of Silence which is sought to prevent violations of discipline and Police Republic of Indonesian 's code of ethics. The difference between this research is Sarah Marshall's research (2019: 11) conducted with a qualitative approach while this research uses quantitative. The update in this study is this research examines the problem of members' perspectives regarding the Blue Code of Silence that develops in Police Republic of Indonesian organizations along with the understanding of HR Police Republic of Indonesian organizations regarding the use of information technology on the application of the whistle blowing system in Police Republic of Indonesian organizations, whereas in Sarah Marshall's research (2019: 6) is the delivery of criticism of Police Officers who use Blue Code of Silence against violations that exist in their organization.

\subsection{Whistleblowing}

Hamid and Zainuddin (2015: 480) define that the whistleblowing action of an action taken by a member of an organization or a former member of an organization that has seen a violation or deviation committed by members of the organization within the scope of authority in the organization which is then reported to the parties the party considered can take action on violations that have been committed. Graycar and Prentzler (2013: 31) call whistleblowing as an action to prevent a violation that exists in a police organization. Whistleblowing itself is one of the acts committed by someone both inside the organization or outside the organization who feels disagreeing and needs to take action on violations or crimes committed by someone so that no form of crime or violation will be repeated in the future.

Miceli and Near (1992 in Jeon, 2017: 5) divide whistleblowing in two ways, namely internal whistleblowing and external whistleblowing. Internal whistleblowing itself is defined as a way for a worker to report errors to a supervisor or other people in an organization that have the ability to correct these errors. External whistleblowing itself is defined as reporting outside the organization that is considered to have the authority to change a violation.

Weisburd (2000: 5) argues that almost every member of the police force in the United States feels that whistleblowing is a useless act and two-thirds feel that 
whistleblowing is a useful thing. In addition, it was found in the study that half of the police officers considered that not reporting police irregularities was normal and three-fifths of the police members did not agree to report violations committed by their members.

The regulation regarding whistleblowing actually exists within the police and has been ratified through the National Police Decree No.21 of 2012 concerning Protection of Reporting Violations of Law in the Police Environment. However, to date, very few criminal cases have originated from whistleblowing. This was triggered by the Blue Code of Silence norm

where a member of the police force is considered taboo to report irregularities committed by other members of the police force.

The police itself can be said to be an organization that has high loyalty and integrity so that sometimes some members have an excessive level of loyalty. In addition, several studies suggest that one of the reasons that suppress whistleblowing is fear of retaliation (Cho and Song, 2015; Jeon 2017). The whistleblowers in the police organization will get negative stigma from other members and will get a response either directly like bullying or indirectly as ostracized by their colleagues.

Research on whistleblowing conducted by Holgersson (2019) states that $88 \%$ of police officers in Sweden are afraid of retaliation when doing internal whistleblowing and $95 \%$ of police officers are afraid of retaliation when doing external whistleblowing. One of the real cases happened to a policeman in Queensland, Australia where his colleagues in the police find fault with him because the police opened the fault of his colleague in the police who gave the address of victims of domestic violence to the perpetrators (Smee, 2019).

Hartono and Cahaya (2017: 50) in their research explained that whistleblowing can be seen from the following conditions:

Whistleblowing Judgment, is a decision to report fraud or violations in the organization. each individual has the same right to be professional and make decisions in conducting the behavior to become a whistleblower.

Situational Factors, greatly influences a person's intention to become a whistleblower. This happens because a person can behave in a certain way that is controlled by the factors of seriousness of error, fear of retaliation, and the costs that must be incurred personally for the reporting made. These situational factors can subsequently become a motivating and inhibiting factor for someone to become a whistleblower in his work environment and in the community.

Self Efficacy, is a person's feelings towards their ability to overcome problems. These feelings have an impact on a belief that is in someone where someone will be shown through how one's behavior in solving various problems that befall him. In implementing yourself as a Whistleblower, this self-efficacy contributes to the feeling of justification in carrying out the tasks performed.

Based on the three aspects of dimensions which are explained above, it can be seen that in a research a whistleblowing can be measured through whistleblowing judgment, situational factors and self 
efficacy.

Urumsyah, Saputra and Wicaksono (2018: 359) conducted a study explaining whistleblowing that was influenced by moral intensity, organizational commitment and professional commitment. This research was conducted by quantitative methods to government employees in the DIY provincial government. The analysis technique used is partail least square analysis (PLS). The results of Urmumsyah, Saputra and Wicaksono's research (2018: 364) explained that only organizational commitment variables did not have a significant effect on whistleblowing while on moral intensity and professional commitment variables had a significant influence on the desire to report.

The relevance of research literature Urmumsyah, Saputra and Wicaksono (2018: 359) with this research is about whistleblowing. The difference between this study and Urmumsyah, Saputra and Wicaksono (2018: 364) research is that Urmumsyah, Saputra and Wicaksono (2018) research examines the influence of moral intensity, organizational commitment and professional commitment to whistleblowing, while this research emphasizes the influence of the Blue Code of Silence against whistleblowing. The renewal of this research is that this study examines the problem of members' perspectives on the Blue Code of Silence that develops in Police Republic of Indonesian organizations along with the understanding of HR Police Republic of Indonesian organizations regarding the use of information technology to the application of whistle blowing systems in Police Republic of Indonesian organizations, while in operational variables that exist in Urmumsyah, Saputra and Wicaksono (2018: 364) in no way explains the tendency of the Blue Code of Silence in their organizations.

\section{METHOD}

The research method used in this study is a survey research method that uses the rules of positivistic. According to Adiyanta (2019: 700) is a research activity carried out by collecting information from respondents who become research samples to find out how the views of an issue that can use a questionnaire. Survey research using this questionnaire aims to enable respondents to fill out questionnaires without any pressure and can fill according to their wishes given the respondents' answers written on paper and without directly meeting the researchers. In terms of positivistic rules, Sugiyono (2017: 7) states that in research that uses postivistic rules will explain social phenomena through numbers presented in statistical form. These rules are in accordance with this study where research on the influence of the Blue Code of Silence on Whistleblowing conducted in Semarang Criminal Investigation Unit will be presented with data in the form of numbers and statistics derived from a causal relationship arising from the independent variables on the dependent variable.

\subsection{Population}

Population is the whole of a unit characteristic that is the object of research measured (Arikunto, 2002: 3). The population that is the main focus of this study is all members of the National Police who are assigned to the Criminal Investigation Unit at the Semarang Police District Police which have a total of 150 members.

\subsection{Sample}

The research sample is part of the population that has certain characteristics, characteristics or circumstances to be measured (Arikunto, 2002: 4). In this case 
the sample was taken from members of the police who served the Reksrim function at Semarang Police Resort. The sampling technique itself uses a systematic random technique, which is a sampling method by systematically randomizing homogeneous samples (Priyono, 2016: 111). From the systematic random sampling technique, several members of the Semarang Criminal Police Unit were chosen as the

$$
\begin{aligned}
& \mathrm{n}=\frac{\mathrm{N}}{(1+N . e 2)} \\
& \mathrm{n}=\frac{150}{(1+150 .(0,1) 2)} \\
& \mathrm{n}=\frac{150}{(1+1,5)} \\
& \mathrm{n}=60
\end{aligned}
$$

Through the calculation of the number of samples based on the Slovin formula, it is found that the ideal number of sample sizes is a minimum of around 60 people. The number of calculations in the sample is in line with the opinion of Roscoe (1982: 253) where he states that the number of samples used in a community measurement has a number of eligibility where the number is 30 to 500 people which is in line with the data analysis requirements using analysis regression where the minimum sample size must total approximately 10 times the number of variables used both as the number of independent and bound variables in the study (Sugiyono, 2017: 90).

\subsection{Data Collection Techniques}

The use of surveys is expected to be able to see a trend or tendency that exists in a population that is the target of research (Crowther Dowey and Fussey, 2013: 102). The survey itself was carried out by distributing questionnaires to respondents to be filled in accordance with what they thought through indicators strongly disagree to strongly agree indicated by the Likert scale.

Through the survey it is hoped that it can sample for this study. The chosen work unit was the Criminal Investigation Unit at the Semarang Police District considering its task in handling every criminal case which always directly touches both witnesses and suspects in a matter.

To find out the size of the sample this study used the Slovin formula (Priyono, 2016: 120), with a population of 150 , where:

Notes:

n: sample size

$\mathrm{N}$ : population size

e: percentage of errors desired or tolerated $(10 \%)$

gather the views of members of the Criminal Investigation Unit and so that members of the Criminal Investigation Unit can give their views without fear in the delivery given that the identity of the respondent's name is kept secret by the researcher.

\subsection{Normality Test}

Normality test is a test that is used to see how the distribution conditions exist in the research variables which can be seen visually by looking at the form of distribution such as kurtosis or skew that can be seen from the graph or scatterplot and then a comparison between the normal distribution with our distribution possess so that it can be seen the normality of the existing variables (Field, 2009: 134; Ghozali, 2005: 110). If the distribution of the variable is not found normality, it can be considered an invalid variable so that the regression model test cannot be carried out considering the condition of the regression test is the normality of the variables used.

Examination on the assumption of normality itself can be seen from scatterplot examination which is said to have a normal distribution if there are 
residuals distributed randomly in the picture and the points are collected close to and around the 450 straight line. If the residual points are scattered and located far from the straight line, it can be ascertained that the distribution has irregularities or abnormal so that the analysis with regression models cannot be done considering the normality of data is one of the regressions test requirements.

\section{Simple Linear Regression}

Simple Regression Analysis is a data analysis technique performed to predict the outcome variable results from one predictor variable (Field, 2009: 198). This study using a simple regression analysis model was applied to determine the effect of the independent variable, the Blue Code of Silence on whistleblowing in the scope of the Semarang Criminal Investigation Unit. The simple linear regression model calculation model itself has the following formula:

\section{A. T-Test}

Hypothesis testing using t test is a test that is done partially in research. This test has the following criteria:

\section{a) Hypothesis Formulation}

$\varpi \mathrm{H} 0: \beta 1=0$, which means there is no significant influence of the independent variable $(\mathrm{X})$ partially on the dependent variable $(\mathrm{Y})$.

$\varpi \mathrm{Ha}: \beta 1 \neq 0$, which means that there is a significant influence of the independent variable

(X) partially on the dependent variable (Y).

b) Determination of the critical value

$\varpi$ Significance level $\alpha=5 \%$

$\varpi$ Degree of freedom: $\mathrm{dk}=\mathrm{n}-\mathrm{k}-1$ Where:

$\mathrm{n}=$ number of samples (60 respondents)

$\mathrm{k}=$ number of independent variables (2 variables) $\mathrm{t}$ table; $\mathrm{t}(\alpha / 2: \mathrm{dk})$ c) Determine the testing criteria

$\varpi \mathrm{H} 0$ is accepted if: $-t$ arithmetic $>-t$ table or $\mathrm{t}$ arithmetic $<\mathrm{t}$ table and significance $\alpha>$ 0.05

$\varpi \mathrm{H} 0$ is rejected if: $\mathrm{t}$ count $>\mathrm{t}$ table or $\mathrm{t}$ count $<-\mathrm{t}$ table and significance $\alpha<0.05$

d) Conclusions

-If - $\mathrm{t}$ count $>$ - $\mathrm{t}$ table and $\mathrm{t}$ count $<\mathrm{t}$ table and significance $>0.05$, then the decision is to accept H0, which means the independent variable $(\mathrm{X})$ has no influence on the dependent variable (Y).

-If $-\mathrm{t}$ arithmetic $<-\mathrm{t}$ table and $\mathrm{t}$ arithmetic $>$ $\mathrm{t}$ table value, and significance $\alpha<0.05$, the decision is to reject $\mathrm{H} 0$, which means the independent variable (X) affects the dependent variable $(\mathrm{Y})$.

\section{B. Test-F}

F test is a test that is used to test whether the independent variables have a significant influence on the dependent variable together. In this $\mathrm{F}$ Test, the significance level used was 5\% (Ghozali, 2005). The form of the hypothesis is:

- If $\mathrm{F}$ arithmetic $<\mathrm{F}$ table, then $\mathrm{Ho}$ is accepted if $\operatorname{sig}>\alpha=0.05$

- If $\mathrm{F}$ arithmetic $>\mathrm{F}$ table, then $\mathrm{Ho}$ is rejected if $\operatorname{sig}<\alpha=0.05$

\section{Test the Coefficient of Determination}

Tests conducted on the coefficient of determination that exists in this study aims to find out how the influence that comes from the independent variable is the Blue Code of Silence variable on the dependent variable that is the whistleblowing variable. The use of the coefficient of determination test is described in the formula as follows:

$\mathrm{R}=\mathrm{R} 2 \times 100 \%$

Where:

$\mathrm{R}=$ coefficient of determination $\mathrm{R} 2=$ correlation coefficient 


\section{RESULTS}

4.1. Normality Test

Table 2. Normality Test using Kolmogorov-Smirnov

\begin{tabular}{|cc|r|r|}
\hline & & \multicolumn{1}{|c|}{ X } & \multicolumn{1}{|c|}{ Y } \\
\hline $\mathrm{N}$ & Mean & 35,2500 & 60 \\
& Std. Deviation & 3,34271 & 24,1667 \\
Normal Parametersa,b & Absolute &, 096 & 2,63076 \\
& Positive &, 096 &, 145 \\
Most Extreme & & &, 145 \\
Differences & Negative &,- 072 & \\
& &, 742 &,- 075 \\
Kolmogorov-Smirnov Z & &, 641 & 1,122 \\
Asymp. Sig. (2-tailed) & &, 161 \\
\hline
\end{tabular}

a. Test distribution is Normal.

b. Calculated from data.

In testing the normality in addition to using the Kolmogorov-Smirnov (K-S) test than that the feasibility of data distribution can also be seen through the scatterplot image below:

\subsection{Results of Data Analysis}

Effects of the Blue Code of Silence on Whistleblowing on members of the

\begin{abstract}
Semarang Criminal Investigation Unit. After all the classic assumption tests have been carried out, the next step is to look at the results of the analysis in the simple linear regression test in this study. Based on the results of the analysis of this simple linear regression test, it is known that this simple linear regression equation can be seen from the table below:
\end{abstract}

Table 3 Simple Linear Regression Equations

\begin{tabular}{|c|c|c|c|}
\hline \multirow[t]{2}{*}{ Model } & \multicolumn{2}{|c|}{ Unstandardized Coefficients } & Standardized Coefficients \\
\hline & $B$ & Std.Error & Beta \\
\hline $\begin{array}{ll} & \text { (Constant) } \\
1 & \mathrm{X}\end{array}$ & $\begin{array}{l}14,943 \\
0,262\end{array}$ & $\begin{array}{l}3,451 \\
0,097\end{array}$ & 0,332 \\
\hline
\end{tabular}

a. Dependent Variable: Y

Source: Output SPSS19

Based on the table, it is known that the simple linear regression equation in this study is $Y=14.943+0.332 \mathrm{X}$. Based on these equations it can be seen that the constant 14.943 indicates that the desire to whistleblowing in the Semarang Resort Police Detective Unit if without taking into account the perception of the Blue Code of Silence has a value of 14,943 units. If the Blue Code of Silence variable rises by one unit then Whistleblowing will increase by 0.332 or vice versa if the Blue Code of Silence variable decreases by one unit then the value of the Whistleblowing 
variable will decrease.

The findings of this simple linear

regression equation are also supported by the findings of the following t-test results

Table 4 T-Test Result

\begin{tabular}{|c|c|c|}
\hline Model & $\mathrm{T}$ & Sig. \\
\hline (Constant) & 4,331 & 0,000 \\
1 & 2,685 & 0,009 \\
\hline
\end{tabular}

a. Dependent Variable: Y

Source: Output SPSS19

Seeing the results of the t test, it shows that the Hal hypothesis or the perception of the Blue Code of Silence influences the desire to do whistleblowing at the Semarang Resort Police Detective Unit accepted. Acceptance of this hypothesis can be observed at the $t$ value of 2.685 and the significance value of 0.009 is smaller than the significance level of $5 \%$ or 0.05 . Given these conditions, it can be stated that the perception of the Blue Code of Silence hypothesis influences the desire to do whistleblowing at the Semarang Resort Police Detective Unit accepted. Acceptance of this hypothesis is also strengthened again by looking at and comparing the significance value of the personality (0.019) which is smaller when compared with the value of 0.05 . Thus, the results of this calculation indicate that partially the perception of the Blue Code of Silence hypothesis influences the desire to do whistleblowing at the Semarang Resort Police Detective Unit accepted.

These findings are also strengthened by this $\mathrm{F}$ test which is used to explain the simultaneous influence of the perception of the Blue Code of Silence effect

of the desire to whistleblow at the Semarang Resort Police Detective Unit as presented below:

Table 5 F-Test Result

\begin{tabular}{|ll|l|l|l|l|l|}
\hline Model & Sum of Squares & Df & Mean Square & F & Sig. \\
\hline \multirow{2}{*}{$\begin{array}{l}\text { Regression } \\
\text { Residual }\end{array}$} & 45,137 & 1 & 45,137 & 7,208 & $0,009 \mathrm{~b}$ \\
& Total & 408,197 & 58 & 6,262 & & \\
\hline
\end{tabular}

The data above shows that the $\mathrm{F}$ value is 7.208 and significant at 0.009 . This shows that the perception of the Blue Code of Silence simultaneously influences the desire to do whistleblowing at the Semarang Police Resort Criminal
Investigation, so that this regression model is declared fit or feasible.

The findings of acceptance of this hypothesis are also reinforced by the findings test the following coefficient of determination:

Table 6 Determination Coefficient Test Results 


\begin{tabular}{|l|l|l|l|l|}
\hline Model & $\mathrm{R}$ & R Square & Adjusted R Square & Std. Error of the Estimate \\
\hline 1 & $0,413 \mathrm{a}$ & 0,170 & 0,110 & 2,48177 \\
\hline
\end{tabular}

a. Predictors: (Constant), X4, X2, X1, X3

b. Dependent Variable: Y

Source: Output SPSS19

Based on the table, it can be seen that the adjusted $\mathrm{R}$ Square value in this determination coefficient can be used to explain the perception ability of the Blue Code of Silence in explaining its effect on the desire to whistleblowing at the Semarang Resort Police Detective Unit, where the adjusted $\mathrm{R}$ Square value of 0.095 is means that the perception of the Blue Code of Silence is able to explain its effect on the desire to do whistleblowing at the Semarang Resort Police Detective Unit at $9.5 \%$. The lack of perception ability of the Blue Code of Silence in explaining its influence on the desire to whistleblowing at the Semarang Resort Police Detective Unit, is caused by the condition of the desire to whistleblowing at the Semarang Resort Police Detective Unit which is influenced by members' fears of retaliation or other variables did not participate in this study, this was explained so because from the data processing it is known that other variables were not examined but contributed to the desire to whistleblowing at the Semarang Resort Police Detective Unit such as job satisfaction, work motivation, member discipline, amounting to $91,5 \%$.

B. Results of Partial Analysis of the Independent Variables on the dependent variable

Based on the results of the analysis of all these classic assumption tests that can be used to express the feasibility of this multiple linear regression model, the next step is to look at the results of the analysis on the multiple linear regression test.

Based on the results of the analysis of this multiple linear regression test, the equation is known

\section{Coefficientsa}

Table 7 Multiple linear regression test result

\begin{tabular}{|c|c|c|c|c|}
\hline \multicolumn{2}{|c|}{ Model } & \multicolumn{2}{|c|}{ Unstandardized Coefficients } & \multirow{2}{*}{\begin{tabular}{|l} 
Standardized Coefficients \\
Beta
\end{tabular}} \\
\hline \multicolumn{2}{|c|}{ liodel } & B & Std. Error & \\
\hline \multirow{5}{*}{1} & (Constant) & 15,020 & 3,836 & \\
\hline & $\mathrm{X} 1$ & 0,308 & 0,247 & 0,158 \\
\hline & $\mathrm{X} 2$ & 0,141 & 0,156 & 0,114 \\
\hline & $\mathrm{X} 3$ & 0,627 & 0,236 & 0,343 \\
\hline & $\mathrm{X} 4$ & 0,116 & 0,182 & 0,083 \\
\hline
\end{tabular}


a. Dependent Variable: Y

it can be seen that the constant 15.020 shows that the desire to whistleblowing at the Semarang Resort Police Detective Unit if without taking into account loyalty, seriousness of violations, fear of retaliation and the influence of leadership has a value of 15,020 units. In variable X3, the fear of retribution if one unit increases, the value of the Whistleblowing variable will increase by 0.308 .

The findings of this simple linear regression equation are also supported by the findings of the following t-test results:

\section{Coefficientsa}

Tabel 8. T-test results

\begin{tabular}{|l|l|l|}
\hline Model & T & Sig. \\
\hline (Constant) & 3,916 & 0,000 \\
X1 & 1,245 & 0,218 \\
1 X2 & 0,902 & 0,371 \\
X3 & 2,654 & 0,010 \\
X4 & 0,639 & 0,526 \\
\hline
\end{tabular}

a. Dependent Variable: Y

Based on table 8 , it can be seen that ;

The value of Whistleblowing (Y) of 1.245 and the significance value of 0.218 is greater than the significance level of $5 \%$ or 0.05 . Based on the comparison value of the significance, this means that lies in the area hal is rejected, and hol is accepted, so that the partial hypothesis is presentthe influence of loyalty (X1) on the desire to do whistleblowing (Y) rejected.

Test of Influence between seriousness of violation $(\mathrm{X} 2)$ on the desire to do whistleblowing (Y). Based on statistical testing with SPSS, the count between the seriousness of the violation (X2) to the desire to do whistleblowing ( $\mathrm{Y}$ ) is 0.902 and the significance value of 0.371 is greater than the significance level of $5 \%$ or 0.05. Based on the comparison value of the significance, this means that lies in the area ha 2 is rejected, and ho 2 is accepted, so that partially the hypothesis there is an influence of the seriousness of the violation (X2) on the desire to do whistleblowing $(\mathrm{Y})$ is rejected.

Test of Influence between fear of retaliation (X3) on the desire to whistleblowing (Y)

Based on statistical testing with SPSS, the count between the fear of retribution (X3) of the desire to whistleblowing $(\mathrm{Y})$ is 2.654 and the significance value of 0.010 is smaller than the significance level of $5 \%$ or 0.05 . Based on the comparison value of the significance, this means that it is located in the area ha3 accepted, and ho3 is rejected, so that partially the hypothesis there is the influence of fear of retaliation (X3) against the desire to do whistleblowing (Y) is accepted.

Test of Influence between the influence of leadership (X4) on the desire to do whistleblowing (Y)

Based on statistical testing with SPSS, the 
count between the influence of leadership (X4) on the desire to do whistleblowing (Y) is 0.639 and the significance value of 0.526 is greater than the significance level of $5 \%$ or 0.05 . Based on the comparison value of the significance, this means that lies in ha4 area is rejected, and ho4 is accepted, so that partially the hypothesis of the influence of leadership (X4) on the desire to do whistleblowing $(\mathrm{Y})$ is rejected.
C. Results of Simultaneous Effects of Independent Variables on Bound Variables.

To analyze the simultaneous influence can be seen through this F test which is used to explain the simultaneous influence of loyalty, the seriousness of violations, fear of retaliation and the influence of the leadership influence on the desire to do whistleblowing at Semarang Resort Police Detective Unit as presented below:

Tabel 9 Output F-Test ANOVAa

\begin{tabular}{|c|c|c|c|c|c|c|}
\hline \multicolumn{2}{|l|}{ Model } & Sum of Squares & df & Mean Square & $\mathrm{F}$ & Sig. \\
\hline \multirow{3}{*}{1} & Regression & 69,578 & 4 & 17,394 & 2,824 & $0,033 b$ \\
\hline & Residual & 338,755 & 55 & 6,159 & & \\
\hline & Total & 408,333 & 59 & & & \\
\hline
\end{tabular}

a. Dependent Variable: $Y$

b. Predictors: (Constant), X4, X2, X1, X3

The data above shows that the $\mathrm{F}$ value is 2.824 and significant at 0.033 . This shows that loyalty, seriousness of violations, fear of retaliation and the influence of the leadership simultaneously influence the desire to whistleblowing at the Semarang Police Resort Criminal Investigation, so that this regression model is declared fit or feasible.

The findings of acceptance of this hypothesis are also reinforced by the following findings of the coefficient of determination test:

Table 10 Determination Coefficient Test Results

\begin{tabular}{|l|l|l|l|l|}
\hline Model & R & R Square & Adjusted R Square & Std. Error of the Estimate \\
\hline 1 & $0,413 \mathrm{a}$ & 0,170 & 0,110 & 2,48177 \\
\hline
\end{tabular}

a.

Predictors: $x$ (Constant), $\mathrm{X} 4, \mathrm{X} 2, \mathrm{X} 1, \mathrm{X} 3$

b. Dependent Variable: Y Source: Output SPSS19 
Based on the table, it can be seen that the adjusted $\mathrm{R}$ Square value in the determination coefficient test can be used to explain the ability of the loyalty variable, the seriousness of the violation, fear of retaliation and the influence of the leadership in explaining its influence on the desire to whistleblowing at the Semarang Resort Police Detective Unit, where the value of Adjusted R Square of 0.110 has the meaning that loyalty, seriousness of violations, fear of retaliation and the influence of the leadership is able to explain its influence on the desire to do whistleblowing at the Semarang Resort Police Detective Unit is $11 \%$. While for the other $89 \%$, it is influenced by variables other than those different from those studied but still influences the Whistleblowing variable. This shows that the value is very small so that the variable is difficult to use in further research.

\section{DISCUSSION}

\subsection{Effect of the Blue Code of Silence on the Desire to Conduct Whistleblowing at the Semarang Police Resort Criminal Investigation}

Based on the research findings it is known that the results of data analysis aimed at finding out the effect of the Blue Code of Silence on the desire to do whistleblowing at the Police Detective Unit Semarang Resort, viewed based on a simple linear regression equation, obtained a value of $Y$ $=14,943+0.262 \mathrm{X}$. Based on these equations, it can be seen that the constant 14.943 shows that the desire to whistleblowing at the Semarang Police Criminal Investigation Unit if without taking into account the perception of the Blue Code of Silence has a value of 14,943 units, and if the desire to do whistleblowing at the Semarang Policerest Satreskrim is added to the perception variable of the Blue Code of Silence Silence, the desire to do whistleblowing at the Semarang Police Resort Criminal
Investigation Unit will increase by 0.262 units.

Based on this explanation, it can be seen that the perception of the Blue Code of Silence has an influence on the desire to do whistleblowing at the Semarang Police Resort Criminal Investigation Unit. This explanation is also in accordance with the acceptance of the following hypothesis which shows that the hypothesis hal or the perception of the Blue Code of Silence influences the desire to do whistleblowing at the Semarang Police Resort Criminal Investigation accepted. Acceptance of this hypothesis can be observed at the $t$ value of 2.685 and the significance value of 0.009 is smaller than the significance level of $5 \%$ or 0.05 . Given these conditions, it can be stated that the perception of the Blue Code of Silence hypothesis influences the desire to whistleblowing at the Semarang Police Resort Criminal Investigation accepted. Acceptance of this hypothesis is also strengthened again by looking at and comparing the significance value of the personality (0.019) which is smaller when compared with the value of 0.05 . Thus, the results of these calculations indicate that the partial perception of the Blue Code of Silence hypothesis influences the desire to do whistleblowing at the Semarang Policerest Criminal Investigation Unit accepted.

There is an influence of the Blue Code of Silence norm applied by members of the Semarang Police Resort Secretariat to the desire to conduct whistleblowing can be caused by the culture in the police institution that tends to be covered up from the public so that their image remains positive in the public eye. This makes weak law enforcement against fellow members of the police. This condition is also supported by the existence of the Blue Code of culture

Silence in the police force results in omission and may be able to cover up corruption committed by members of the police force which can damage the foundation of the law enforcement system 
(Ivkovic and Shelley, 2008: 447). Of course, the existence of a culture like this will make a negative tolerance from a good police officer to a bad police member so that the police image as a law enforcement institution will get worse.

Whistleblowing is a program that is aimed at preventing, eliminating and reducing violations committed by members of the Indonesian National Police, but these conditions are seemingly obstructed by the existence of the norm of the Blue Code of Silence. So that the existence of these norms tends to make passive selfawareness of the members to report on acts of fraud or acts of violation of the code of conduct committed by these members, so this hinders law enforcement efforts against these colleagues.

This proves that the Blue Code of Silence also exists in the police in Indonesia, especially in the Semarang Police Criminal Investigation Unit which then influences how the police see and act regarding crimes or violations committed by other police members. The results of this study have similarities with research conducted by Westley (in Ivkovic et al, 2018: 1), Ivkovich (2005: 85), Ivkovich and Shelley (2018: 448) and Rothwell and Baldwin (2007: 3) which explain that members of the police force considers the Blue Code of Silence as a necessity where other members can protect and even cover up members of the police who commit violations or crimes.

\subsection{Influence of loyalty, seriousness of violations, fear of retaliation and partial influence of leadership on the desire to whistleblowing at the Police Detective Unit Semarang Resort}

Based on the research findings it is known that the results of data analysis shown to determine the effect of loyalty, seriousness of violations, fear of retaliation and partial influence of leaders on the desire to do wistleblowing at the Semarang Police
Resort Criminal Investigation, which is seen in the simple linear regression equation obtained value is $Y=15,020+$ $0.343 \mathrm{X} 3$. Based on these equations, it can be seen that the constant 15.020 shows that the desire to whistleblowing at the Police Criminal Investigation Unit in Semarang if without taking into account loyalty, seriousness of violations, fear of retaliation and the influence of the leader has a value of 15,020 units.

If the desire to do whistleblowing at the Semarang Policerest Satreskrim added 1 variable fear of retaliation, the desire to do whistleblowing at the Policerest Satreskrim Semarang will increase by 0.343 units.

Based on these explanations, it can be analyzed the influence of loyalty, seriousness of violations, fear of retaliation and the influence of leadership partially on the desire to wistleblowing at the Semarang Police Resort Criminal Investigation explained as follows:

\subsection{Effect of Loyalty on Willingness Whistleblowing}

Based on the analysis of the influence between loyalty to the desire to do whistleblowing, the hypothesis was rejected. The explanation is also in accordance with the t-count between the loyalty of the desire to do whistleblowing of 1.245 and the significance value of 0.218 is greater than the significance level of $5 \%$ or 0.05 . Based on the comparison value of the significance, this means that lies in the area Hal is rejected, and Hol is accepted, so that partially the hypothesis of the influence of loyalty on whistleblowing is rejected.

This is different from the results of research conducted by Ivkovich (2005: 80) where loyalty is one of the reasons why members prefer to remain silent. Members chose to remain silent because they chose to remain silent given the strong sense of 
brotherhood among police members so that they could not report corrupt police members. In the Semarang Police Criminal Investigation Unit itself loyalty is not an important reason for members to do the Blue Code of Silence and not report other members

\subsection{The influence between the seriousness of the violation on the desire to do whistleblowing}

Based on testing in the influence of the seriousness of the violation of the desire to do whistleblowing experiencing rejection of the hypothesis. The explanation is in accordance with the results of the seriousness of the violation test (X2) of the desire to do whistleblowing (Y) of 0.902 and the significance value of 0.371 is greater than the significance level of $5 \%$ or 0.05. Based on the comparison value of the significance, this means that lies in the $\mathrm{Ha} 2$ area is rejected, and $\mathrm{Ho} 2$ is accepted, so that partially the hypothesis there is an influence of the seriousness of the violation of the desire to do whistleblowing is rejected.

This explanation is also strengthened by the desire to do whistleblowing at the Semarang Policerest Criminal Investigation if added by one variable the seriousness of the violation, the desire to do whistleblowing at the Policerest Criminal Investigation Semarang will increase by 0.141 units. The rejection of the hypothesis in the influence of the seriousness of the violations against the desire to conduct whistleblowing was caused by the seriousness of the police in the police organization.

The results of this study differ from research conducted by Ivkovich and Shelley (2018: 455) where one of the indicators in the study is the seriousness of violations affecting the occurrence of the Blue Code of Silence and the obstruction of Whistleblowing which is the reason for the police to report other members. On

The police study tends to provide personal judgments in which violations or crimes committed by their colleagues are judged by their seriousness. Gratuities in the form of goods given from traders or management of back routes to get a vacation are crimes that have a low probability of being reported while crimes such as item destruction or theft of goods at the crime scene and falsification of reports in drug abuse crimes have a higher likelihood of being reported.

The same results were also found in a study by Rothwell and Baldwin (2007: 351 ) except that the desire to report on serious crimes was more influenced by superiors and colleagues themselves. This is very different from what is in the Semarang Police Criminal Investigation Unit where it does not appear that members of the police feel the seriousness of the violation is not a significant factor to the desire to do Whistleblowing.

\subsection{The influence between fear of retaliation against the desire to whistleblowing}

Based on the analysis conducted in the influence between fear of retaliation against the desire to do whistleblowing there is acceptance of the hypothesis. This explanation is evidenced by the $\mathrm{t}$-count between fear of retaliation against the desire to whistleblowing of 2.654 and a significance value of 0.010 less than the significance level of $5 \%$ or 0.05 . Based on the comparison value of the significance, this means that lies in the area of $\mathrm{Ha} 3$ accepted, and Ho3 is rejected, so that partially the hypothesis there is the influence of fear of retaliation against the desire to do whistleblowing is accepted.

The results of the research at the Semarang Police Criminal Investigation Unit have similarities with the results of research on the secret culture in the Swedish police by Weislander (2019: 320) where members do not want to talk about their colleagues for fear of reprisal in one of the interviews conducted will be forced by other 
members for career development are inhibited, shunned and intimidated and even forced to retire early.

This was also experienced by the police who served in the Central Vigilance Commission (CVC) which played a role in unmasking the crimes committed by corrupt police (Hope, 2016: 168). CVC officers receive various forms of threats and intimidation as a result of the work they have done. This becomes the dominant factor regarding how the CVC can work well given the possibility of threats and intimidation stemming from retaliation directed at them.

The influence of the influence of the leadership on the desire to do whistleblowing

Based on the analysis of the influence of the influence of leadership on the desire to do whistleblowing there is a rejection of the hypothesis. This explanation is reinforced by the existence of t-counts between the influence of leadership on the desire to do whistleblowing of 0.639 and the significance value of 0.526 is greater than the significance level of $5 \%$ or 0.05 . Based on the comparison value of the significance, this means that lies in the Ha4 area is rejected, and Ho4 is accepted, so that partially the hypothesis of the influence of the leadership on the desire to do whistleblowing is rejected.

The findings in this study differ from research conducted by Rothwell and Baldwin (2007: 351) where supervisors or superiors influence the desire to do Whistleblowing but rather lead to reporting on violations that are considered serious. The thing that almost the same is found in research conducted by Ivkovic, Haberfield and Peacock (2018: 184) where direct supervisors have more possibilities to report compared to supervisors who are not direct supervisors. This is different from the results of research conducted at the Semarang Police Criminal Investigation Unit where apparently the influence of the leadership does not significantly influence the desire of members to conduct Whistleblowing.

\subsection{Influence of loyalty, seriousness of violations, fear of reprisal and the influence of the leadership simultaneously on the desire to whistleblowing at at the Semarang Police Resort Criminal Investigation Unit?}

Based on the research findings, it is known from the data analysis that shows that the influence of loyalty, seriousness of violations, fear of retaliation and the influence of the leaders simultaneously on the desire to do whistleblowing at the Semarang Police Resort Criminal Investigation, which is based on the F test counted at 2.824 and significant at 0.033 . This shows that loyalty, seriousness of violations, fear of retaliation and the influence of the leadership simultaneously influence the desire to whistleblowing at the Criminal Investigation Police Semarang, so that this regression model is declared fit or feasible.

This explanation is also reinforced by the determinant findings which state that the adjusted $\mathrm{R}$ Square value in the determination coefficient test can be used to explain the ability of the loyalty variable, the seriousness of the violation, fear of retaliation and the influence of the leader in explaining its influence on the desire to whistleblowing

at the Police Detective Unit Semarang Resort, where the value of adjusted $\mathrm{R}$ Square of 0.110 means that loyalty, seriousness of violations, fear of retaliation and the influence of the leadership are able to explain their influence on the desire to whistleblowing at the Semarang Policerest Satreskrim is $11 \%$.

The lack of loyalty ability, seriousness of violations, fear of retaliation and the influence of leadership in explaining their influence on the desire to whistleblowing at the Semarang Policerest Criminal 
Investigation, is caused by the condition of the desire to whistleblowing at the Policerest Semarang Policerest which is influenced by members' fears of retaliation or variable Others who did not participate in this study were explained as such because of the processed other variables which were not examined but also contributed to the desire to whistleblowing at the Semarang Police Resort Criminal Investigation such as job satisfaction, work motivation, member discipline, amounted to $89 \%$.

There is a simultaneous influence between loyalty, the seriousness of violations, fear of reprisal and the influence of the leadership simultaneously on the desire to do whistleblowing at the Semarang Police Criminal Investigation. All of these aspects can form a norm of the Blue Code of Silence which then influences members in conducting whistleblowing.

\section{CONCLUSION}

The research that has been carried out has the aim to see how the influence of the Blue Code of Silence on Whistleblowing in members of the Semarang Police Criminal Investigation unit, based on the findings and discussion, it can be concluded:

The Blue Code of Silence culture has a significant influence on the Whistleblowing in the Semarang Police Criminal Investigation Unit. This indicates that the members of the Criminal Investigation Unit are still holding fast to the culture of the Blue Code of Silence in deciding whether the member will do Whistleblowing or not. These results then result in differences in real data in the field and data reported on crimes committed by police members

When viewed partially by looking at the various indicators that exist in the Blue Code of Silence and Whistleblowing in members of the Semarang Police Criminal Investigation unit, it can be seen that the most significant indicator is fear of retaliation. It can be concluded that members of the Criminal Investigation Unit refuse to do whistleblowing for fear of the possibility of risk of retaliation from their colleagues or superiors

Analysis of the influence of loyalty, seriousness of violations, fear of retaliation and the influence of leadership simultaneously on the desire to whistleblowing at the Police Secretariat Crime Semarang has an adjusted R Square value of 0.110 which means that loyalty, seriousness of violations, fear of retaliation and influence of leaders able to explain its influence on the desire to do whistleblowing at the Semarang Policerest Criminal Investigation Unit is $11 \%$.

This shows that the influence of loyalty, the seriousness of violations, fear of retaliation and the influence of the leadership simultaneously have little influence in influencing members of the police in conducting Whistleblowing.

\section{IMPLICATION}

In connection with the results of the discussion above and the conclusions of this study, suggestions that can be given by researchers are related to the Effect of the Blue Code of Silence Against the Desire to Conduct Whistleblowing in Members of the Semarang Police Criminal Investigation Unit, the steps that must be taken by the police are:

The need for regulations, counseling and more stringent supervision in order to eliminate the culture of code of silence in the police environment, especially members of the Semarang Police Criminal Investigation unit so as to create good organizational governance.

The need for further research on the variable fear of retaliation is good so that it can get significant results on why the variable fear of retaliation becomes the most prominent in the dynamics that exist in members of the Semarang Police Criminal Investigation unit.

The need for further research by using 
other variables so that to find out the number of $89 \%$ that affects members to do Whistleblowing given the influence of loyalty,seriousnes.REFERENCES:

\section{BOOKS :}

Arikunto, S. 2002. Metode Penelitian Suatu Pendekatan Proposal. Jakarta: PT Rineka Cipta.

Ghozali, Imam. 2005. Aplikasi Analisis Multivariate dengan SPSS. Semarang: Badan Penerbit UNDIP.

Graycar, A dan Prenzel, T. 2013. Understanding and Preventing Corruption. London: Palgrave Macmillan.

Hope Sr., Kempe Ronald. 2016. Police Corruption and Police Reforms in Developing Societies. New York: CRC Press

Ivkovic, Sanja Kutnjak. 2005. Fallen Blue Knights: Controlling Police Corruption. Oxford: Oxford University Press.

Ivkovich, Sanja K. 2015. Measuring Police Intergrity Across the World: Studies from established democracies and countries in Transition. New York: Springer.

Klockars, C.B. , Ivković, S.K. , Harver, W.E. , \& Haberfield, M.R. (2000). The measurement of police integrity. Washington, DC: National Institute of Justice. Marshall, Sarah. 2019. Whistleblowing and Moral Dilemmas In Policing: An Analysis of Police Culture and The "Blue Blue Code of Silence”. Tesis. St. Catharines: Brock University

Ombudsman Republik Indonesia. 2018. Laporan Triwulan I. Jakarta: Ombudsman Republik Indonesia.

Phyman, M., Cohen, J., Boardman, M., Webster, B. dan Seymour, N. 2012. Arresting Corruption in the Police: the global experience of police corruption reform efforts. London: Transparency International UK;
Defence and Security Programme.

Priyono. 2016. Metode Penelitian Kuantitatif. Sidoarjo: Zifatama Publishing.

Robbins, Stephen P. dan Coulter, Mary. 2007. Manajemen. Jakarta: PT. Indeks Roscoe. 1982. Research Methods for Business. New York: Mc Graw Hill.

Sudjana. 2006. Metode Statistik. Jakarta: Rineka Cipta.

Sukarna. 2011. Dasar-dasar Manajemen. Bandung : Mandar Maju

Sugiyono. 2017. Metode Penelitian Kuantitatif, Kualitatif dan $R \& D$. Bandung: AlfaBeta.

Transparency International. 2019. Global Corruption Perception Index 2018. Berlin: Transparency International.

Weisburd, David dan Greenspan, Rosanne . 2000. Police attitudes toward abuse of authority: Findings from a national study. Washington, DC: National Institute of Justice.

\section{Journals :}

Adiyanta, F.C.Susila. 2019. "Hukum dan Studi Penelitian Empiris: Penggunaan Metode Survey sebagai Instrumen Penelitian Hukum Empiris", Adminitrative Law \& Governance Journal, volume 2 artikel 4,hlm. 697-709.

Hamid, Muhammad H. dan Zainuddin, Muhammad. 2015. "Whistleblowing: an Organizational Perspektif", IJRMM, volume 5 artikel 7, hlm. 479-487.

Hartono, Tri dan Cahaya, Fitri Roman. 2017. " Whistleblowing Intention Sebagai Alat Anti Korupsi dalam Institusi Kepolisian", AKUISISI: Journal of Accounting \& Finance, edisi 13 artike 2, hlm. 45-61.

Ivković, Sanja Kutnjak dan Shelley, Tara O'Connor. 2008. "The police Blue Code of Silence and different paths towards democratic policing", Policing and Society: An 
International Journal of Research and Policy, Volume 18 artikel 4, hlm. 445-473.

Ivkovich, Sanja K., Morgan, Skyler J., Mraovic, Irena C. dan Borovec, K. 2018. "Does the police Blue Code of Silence vary with police assignment? An empirical exploration of the relation between the code and assignment", Police Practice and Research: an International Journal, Volume 19 artikel 4, hlm. 1-16.

Jain, A.K. 2017. 'Fighting corruption: contemporary measures in Canada',

Canadian Foreign Policy Journal, volume 23 artikel 1, hlm. 93-116.

Kellers, Jorg. 2014. 'Military Leadership and Leader', ENDC Proceedings, Volume 19, hlm. 26-45.

Rothwell, G. R dan Baldwin, J.N. 2007. 'Ethical Climate Theory, Whistleblowing, and the Blue Code of Silence in Police Agencies in the State of Georgia, Journal of Business Ethics, 70:341-36.

Saha, Sebak K. 2014. "Corruption and Good Governance: The Case of Bangladesh", SUST Journal of Social Science, edisi 22 artikel 2, hlm. 4552.

Soemanegara, Syam. 2003.

"Kepemimpinan Militer: Sejarah SIngkat, Nilai , Prinsip dan ciri khusus", MANAJERIAL, volume 2 artikel 3, hlm. 19-29

Wieslander, Malin. 2019. "Learning the (hidden) silence policy within the police", Studies in Continuing Education, Volume 41 artikel 3, hlm. 308-325.

Yuniarti, Sri. 2011. "POLICE REPUBLIC OF INDONESIAN DI ERA DEMOKRASI: dinamika pemikiran internal", Menggugat Politik Parlemen, Volume 8 artikel 1, hlm. 109-124.

\section{Sources Internet :}

Haryanto, Fefy. 2017. "Kasus Korupsi Makin Menggurita Di Segala
Profesi"

https://www.brilio.net/serius/8jenderal-tniPolice Republic of Indonesian -ini-terjerat-korupsisaat-masih-dinas-aktif-170601x.html. (accessed on 2 January 2019).

KataData. 2017. "Siapa Lembaga Terkorup di

Indonesia"dalam https://databoks.katadata. co.id/datapublish/2017/03/09/dprdianggap-

lembaga-paling-korup. (accessed on 10 January 2019).

Smee, Bee. 2019. " 'I knew there would be repercussions': Queensland police hit whistleblower over historic 'misconduct' " dalam https://www.theguardian.com/australi a-news/2019/nov/08/queenslandpolice-lay-misconduct-chargeagainst-officer-who-testified-aboutforce- privacy-breach (accessed on 10 January 2019).

Suryasumirat, Ratu A. 2018. "8 Polres Ini Raih Predikat Wilayah Bebas Korupsi" dalam:https://www.liputan6.com/new s/read/3662634/8-polres-ini-raihpredikat-wilayah-bebas-korupsi. (accessed on 11 January 2019 